\title{
Oxidative Transformation of Controlled Substances by Manganese Dioxide
}

\author{
Webber Wei-Po Lai, ${ }^{1}$ Angela Yu-Chen Lin, ${ }^{1}$ Sheng-Yao Yang,, and Ching-Hua Huang ${ }^{2}$ \\ ${ }^{1}$ Graduate Institute of Environmental Engineering, National Taiwan University, 71 Chou-Shan Road, Taipei 106, Taiwan \\ ${ }^{2}$ School of Civil and Environmental Engineering, Georgia Institute of Technology, Atlanta, GA 30332, USA \\ Correspondence should be addressed to Angela Yu-Chen Lin; yuchenlin@ntu.edu.tw
}

Received 22 January 2015; Accepted 25 March 2015

Academic Editor: Mehmet A. Oturan

Copyright (c) 2015 Webber Wei-Po Lai et al. This is an open access article distributed under the Creative Commons Attribution License, which permits unrestricted use, distribution, and reproduction in any medium, provided the original work is properly cited.

This study investigated the oxidative transformation of four controlled substances (ketamine, methamphetamine, morphine, and codeine) by synthesized $\mathrm{MnO}_{2}\left(\delta-\mathrm{MnO}_{2}\right)$ in aqueous environments. The results indicated that ketamine and methamphetamine were negligibly oxidized by $\mathrm{MnO}_{2}$ and, thus, may be persistent in the aqueous environment. However, morphine and codeine were able to be oxidized by $\mathrm{MnO}_{2}$, which indicated that they are likely naturally attenuated in aqueous environments. Overall, lower solution $\mathrm{pH}$ values, lower initial compound concentrations, and higher $\mathrm{MnO}_{2}$ loading resulted in a faster reaction rate. The oxidation of morphine was inhibited in the presence of metal ions $\left(\mathrm{Mn}^{2+}, \mathrm{Fe}^{3+}, \mathrm{Ca}^{2+}\right.$, and $\left.\mathrm{Mg}^{2+}\right)$ and fulvic acid. However, the addition of $\mathrm{Fe}^{3+}$ and fulvic acid enhanced codeine oxidation. A second-order kinetics model described the oxidation of morphine and codeine by $\mathrm{MnO}_{2}$; it suggested that the formation of a surface precursor complex between the target compound and the $\mathrm{MnO}_{2}$ surface was the rate-limiting step. Although the target compounds were degraded, the slow TOC removal indicated that several byproducts were formed and persist against further $\mathrm{MnO}_{2}$ oxidation.

\section{Introduction}

The presence of pharmaceuticals in aqueous environments is an important environmental issue because conventional wastewater treatment plants (WWTP) do not remove them, resulting in their release into the environment $[1,2]$. Controlled substances are one type of pharmaceuticals commonly used in hospitals. Besides their medical applications, controlled substances are also used illicitly and abusively. These substances can be classified as antidepressants, stimulants, and hallucinogens based on their effects on the central nervous system. In addition, these compounds can cause significant toxicity after prolonged exposure because they are chemically and biologically active [3]

Ketamine, methamphetamine, morphine, and codeine are four controlled substances and have been detected in various waterbodies in different countries. For example, they were detected in hospital effluents (maximum concentrations of $10,000,260,1,240$, and $378 \mathrm{ng} / \mathrm{L}$, resp.), and ketamine, methamphetamine, and codeine were detected in river water in Taiwan (maximum concentrations of 341,405 , and $57 \mathrm{ng} / \mathrm{L}$, resp.) $[4,5]$. Boleda et al. [6] reported that morphine and codeine were detected at concentrations of up to 81 and $397 \mathrm{ng} / \mathrm{L}$, respectively, in WWTP effluents in Spain. Hummel et al. [7] investigated the occurrence of morphine and codeine in Germany and found that both of these compounds were present in river water (Rhine water) $(78 \mathrm{ng} / \mathrm{L}$; $94 \mathrm{ng} / \mathrm{L}$ ), WWTP influents ( $820 \mathrm{ng} / \mathrm{L} ; 540 \mathrm{ng} / \mathrm{L}$ ), and effluents $(110 \mathrm{ng} / \mathrm{L} ; 260 \mathrm{ng} / \mathrm{L})$. In addition, Castiglioni et al. [8] investigated the occurrence of morphine and methamphetamine in Italy and Switzerland, maximum concentrations of 204 and $16 \mathrm{ng} / \mathrm{L}$, respectively, in the WWTP influent and 55 and $4 \mathrm{ng} / \mathrm{L}$, respectively, in the WWTP effluent. The release of these controlled substances into the aqueous environment may endanger aquatic life and result in ecosystem contamination.

Natural attenuation (hydrolysis, redox reaction, sorption, photolysis, and biodegradation) is considered to be one of the most important pathways for removing contaminants from the aqueous environment and is the most economically 
TABLE 1: Physicochemical properties of ketamine, methamphetamine, morphine, and codeine.

\begin{tabular}{|c|c|c|c|c|c|}
\hline & Molecular formula & $\begin{array}{l}\text { Molecular weight } \\
(\mathrm{g} / \mathrm{mol})\end{array}$ & $\mathrm{pKa}$ & Solubility $(\mathrm{mg} / \mathrm{mL})$ & Structure \\
\hline Ketamine & $\mathrm{C}_{13} \mathrm{H}_{16} \mathrm{ClNO}$ & 237.7 & $7.5^{\mathrm{b}}$ & 250 & \\
\hline Methamphetamine & $\mathrm{C}_{10} \mathrm{H}_{15} \mathrm{~N}$ & 149.2 & $9.9^{\mathrm{a}}$ & NA & \\
\hline Morphine & $\mathrm{C}_{17} \mathrm{H}_{19} \mathrm{NO}_{3}$ & 285.3 & $9.85^{\mathrm{b}}$ (phenol group) & 60 & \\
\hline Codeine & $\mathrm{C}_{18} \mathrm{H}_{21} \mathrm{NO}_{3}$ & 299.4 & $9.8^{b}$ & 434.8 & \\
\hline
\end{tabular}

${ }^{\mathrm{a}}[19],{ }^{\mathrm{b}}[20]$.

feasible method for further attenuation of treated wastewater [9]. However, very limited information is currently available regarding the environmental fates of these four controlled substances (ketamine, methamphetamine, codeine, and morphine), and the oxidative transformation of these four controlled substances by manganese oxide $\left(\mathrm{MnO}_{2}\right)$ has not been previously investigated. $\mathrm{MnO}_{2}$ is abundant in natural sediments and soils and has been reported to possess a powerful oxidative capacity for removing phenol, aniline, aliphatic amine, and triazine in aquatic environments through oxidation and sorption $[10,11]$.

The objective of this study was to investigate the oxidative transformation of four controlled substances (ketamine, methamphetamine, morphine, and codeine) by synthesized $\mathrm{MnO}_{2}\left(\delta-\mathrm{MnO}_{2}\right)$ in an aqueous environment. Several critical environmental factors that may affect the $\mathrm{MnO}_{2}$ oxidation rate were studied, including the $\mathrm{MnO}_{2}$ loading, initial compound concentration, and solution $\mathrm{pH}$. In addition, the effects of cosolutes (metal ions $\left(\mathrm{Mn}^{2+}, \mathrm{Fe}^{3+}, \mathrm{Ca}^{2+}\right.$, and $\mathrm{Mg}^{2+}$ ) and natural organic matter) on $\mathrm{MnO}_{2}$ oxidation were investigated, and total organic carbon removal and oxidative transformation byproducts were studied.

\section{Experimental Setup}

2.1. Chemicals. Morphine, codeine, and ketamine were purchased from Sigma-Aldrich (St. Louis, MO, USA).
Methamphetamine was purchased from the US Pharmacopeial Convention (USP). Without any further purification, the purities of all drugs were greater than $95 \%$. All other stock solutions were prepared in deionized water at concentrations of $500-1,000 \mathrm{mg} / \mathrm{L}$ and were stored at $4^{\circ} \mathrm{C}$ in a refrigerator. Other chemicals were purchased from Merck Millipore (Guyancourt, France), Avantor Performance Materials (Phillipsburg, NJ, USA), Sigma-Aldrich (St. Louis, MO, USA), and Nacalai Tesque (Kyoto, Japan) with purities greater than $85 \%$ (Table S1 in Supplementary Material available online at http://dx.doi.org/10.1155/2015/364170). The physicochemical properties of ketamine, methamphetamine, codeine, and morphine are listed in Table 1.

2.2. Synthesis of Manganese Dioxide. $\delta-\mathrm{MnO}_{2}$ was synthesized according to the methods of Murray [12]. First, $80 \mathrm{~mL}$ of $0.1 \mathrm{M} \mathrm{KMnO}_{4}$ and $160 \mathrm{~mL}$ of $0.1 \mathrm{M} \mathrm{NaOH}$ were added to $1.64 \mathrm{~L}$ of $\mathrm{N}_{2}$-sparged reagent water, and $120 \mathrm{~mL}$ of $0.1 \mathrm{M}$ $\mathrm{MnSO}_{4}$ was added to the solution while continuously stirring. After the $\mathrm{MnO}_{2}$ particles settled, the supernatant solution was replaced with deionized water until the conductivity of the $\mathrm{MnO}_{2}$ suspension was less than $2 \mu \mathrm{S}-\mathrm{cm}^{-1}$. The final volume of the $\mathrm{MnO}_{2}$ solution was adjusted to $1 \mathrm{~L}$, and then the solution was stored at $4^{\circ} \mathrm{C}$.

2.3. Chemical Analysis. High-performance liquid chromatography-tandem mass spectrometry (HPLC-MS/MS) was 


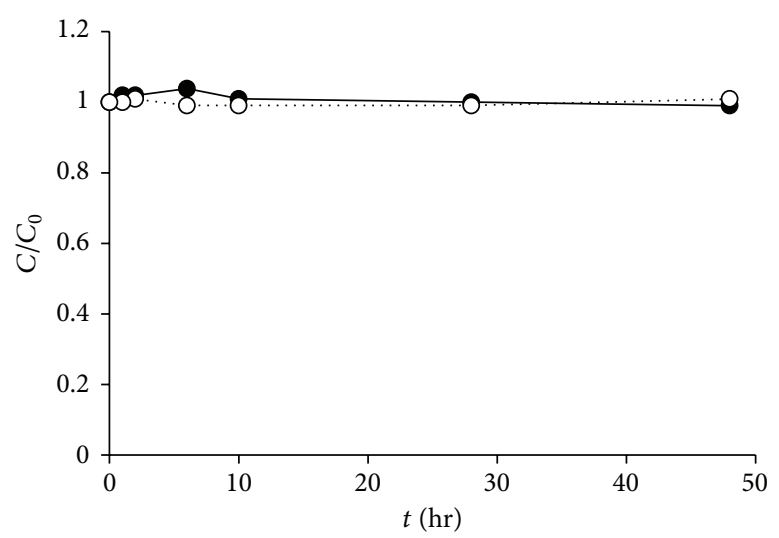
$\begin{array}{ll}- & 10 \mathrm{mg} / \mathrm{L} \mathrm{MnO}_{2} \\ . \mathrm{O} & \text { Without } \mathrm{MnO}_{2}\end{array}$

(a)

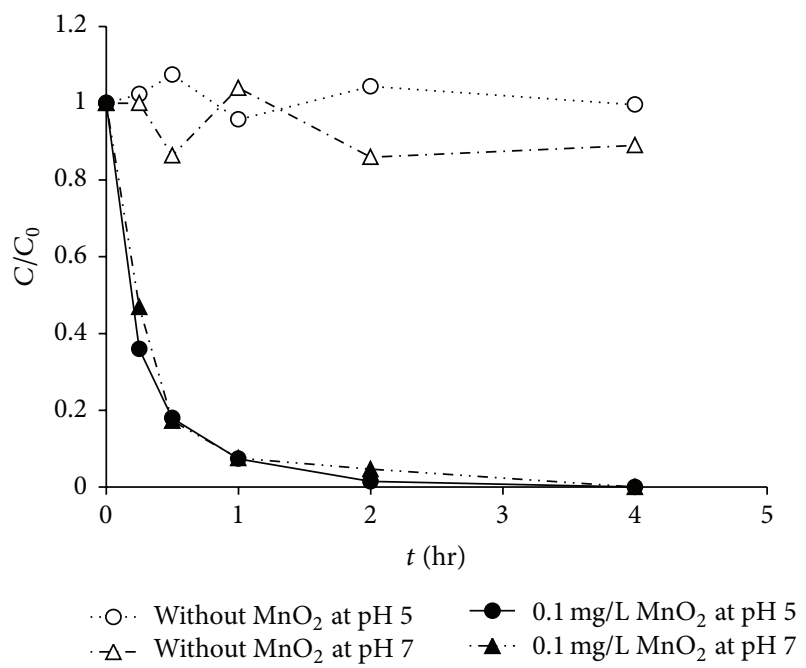

(c)

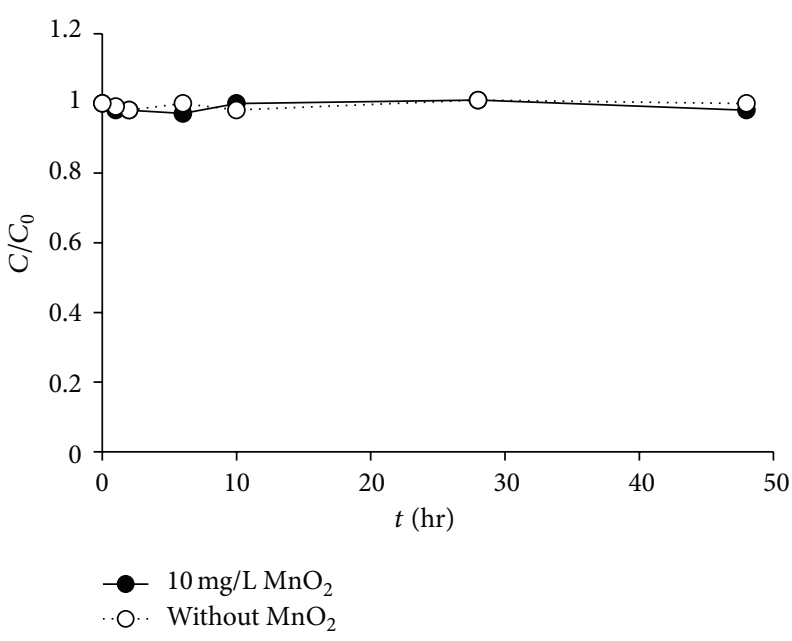

(b)

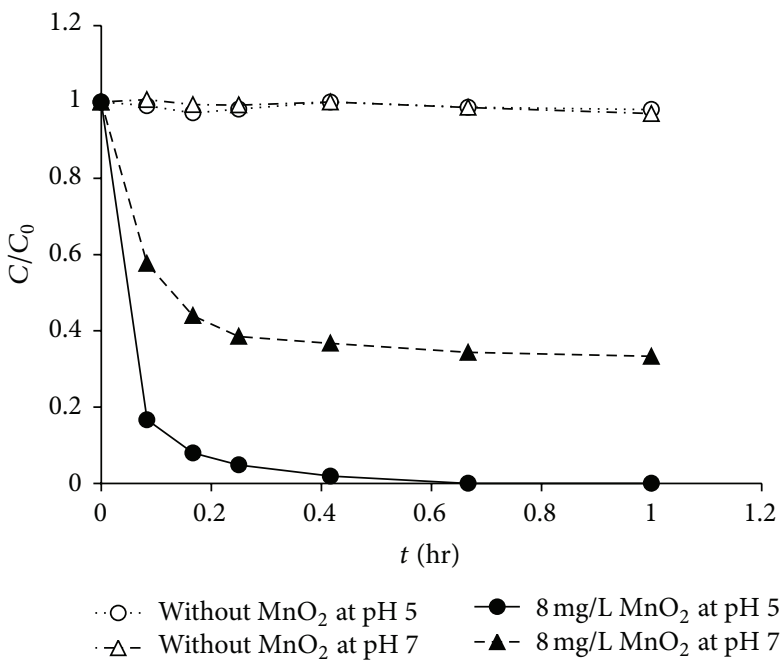

(d)

FIGURE 1: Oxidation of the four controlled substances by $\mathrm{MnO}_{2}$ : (a) ketamine at $\mathrm{pH}$ 5, (b) methamphetamine at $\mathrm{pH}$ 5, (c) morphine, and (d) codeine (compound concentration $=100 \mu \mathrm{g} / \mathrm{L}$, ionic strength $=10 \mathrm{mM}$ ).

used to analyze the concentrations of the four target controlled substances. The HPLC module consisted of a pump (Agilent 1200 Series Binary Pump), degasser (Agilent 1200 Series Micro Vacuum Degasser), and autosampler (Agilent 1200 Series Autosampler). The analytes were determined using chromatography with a ZORBAX Eclipse XDB- $\mathrm{C}_{18}$ column $(150 \times 4.6 \mathrm{~mm}, 5 \mu \mathrm{m}$ particle size $)$ and a flow rate of $1 \mathrm{~mL} \mathrm{~min}^{-1}$. Mobile phases A and B consisted of $0.05 \%$ formic acid with $10 \mathrm{mM}$ ammonium acetate in DI water and methanol, respectively.

2.4. Oxidation of Controlled Substances. $\mathrm{MnO}_{2}$ oxidation experiments were conducted using $250 \mathrm{~mL}$ screw-cap amber glass bottles with aluminum foil septa at room temperature $\left(22^{\circ} \mathrm{C}\right)$. The solution $\mathrm{pH}$ was controlled using a $10 \mathrm{mM}$ acetate buffer ( $\mathrm{pH} 4$ and 5), 4-morpholinepropanesulfonic acid (MOPS) (pH 6 and 7), 2-(cyclohexylamino)ethanesulfonic acid (CHES) ( $\mathrm{pH} 9)$, and a phosphate buffer ( $\mathrm{pH} 9)$. In addition, $\mathrm{NaCl}(0.01 \mathrm{M})$ was added to maintain an appropriate ionic strength.

The volume of the reactor was fixed at $100 \mathrm{~mL}$. The reaction aliquots were collected $(1 \mathrm{~mL})$ and quenched using two different methods: the filtration quenching method and the reductant quenching method. In the reductant quenching method, oxalic acid $(0.5 \mathrm{~g} / \mathrm{L})$ was added to desorb the target compound from the $\mathrm{MnO}_{2}$ surface. The filtration quenching method can only detect target compounds dissolved in solution, not those adsorbed on the surface of manganese dioxide.

2.5. Analysis of Oxidative Byproducts. To analyze the oxidative byproducts of codeine, an Agilent LC-ESI-MS/MS combined with a ZORBAX Eclipse $\mathrm{XDB} \mathrm{C}_{18}$ column $(150 \times$ $4.6 \mathrm{~mm}, 5 \mu \mathrm{m}$ particle size) was used to perform quantitative analyses. Three steps were required to analyze the byproducts. First, the electron-spray ionization (ESI) detector 


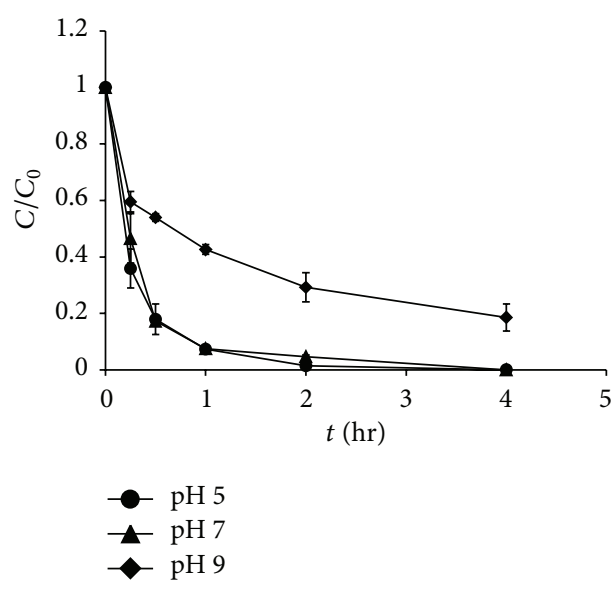

(a)

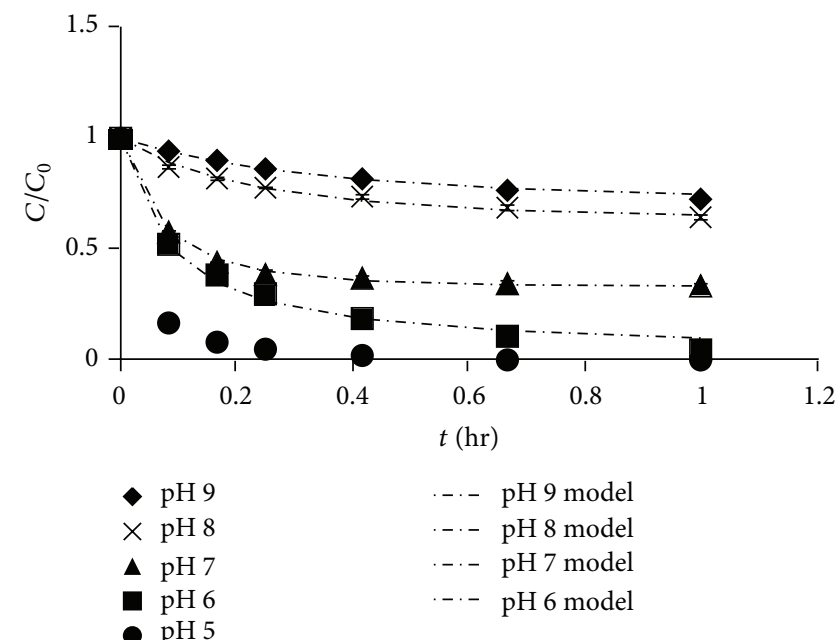

(b)

Figure 2: Effect of solution $\mathrm{pH}$ on the oxidation of controlled substances by $\mathrm{MnO}_{2}$ : (a) morphine (with $100 \mu \mathrm{g} / \mathrm{L} \mathrm{MnO} 2$ ) and (b) codeine (with $8 \mathrm{mg} / \mathrm{L} \mathrm{MnO}_{2}$ ) (morphine and codeine $=100 \mu \mathrm{g} / \mathrm{L}, \mathrm{pH}=7$, and ionic strength $=10 \mathrm{mM}$ ) (the second-order kinetic model developed by Zhang et al. [11] was fitted to describe the codeine oxidation).

was operated to obtain a full mass spectrum scan (Q1 scan) ranging from 50 to 600 . Then, the selected sample was compared with the control sample to determine the possible oxidative byproduct. Second, the multiple-reaction monitoring transition mode (MRM) was used to optimize the parameters for MS/MS detection, including the declustering potential (DP), collision energy (CE), and collision cell exit potential (CXP). Third, the LC parameters were optimized to separate the analyte, including the mobile phase, flow rate, and injection volume.

\section{Results and Discussion}

Background tests (hydrolysis and adsorption) were performed before the $\mathrm{MnO}_{2}$ oxidation experiment. The four controlled substances remained stable in the water at all tested $\mathrm{pH}$ conditions ( $\mathrm{pH} 4$ and 5 for ketamine and methamphetamine; $\mathrm{pH} \mathrm{5,} \mathrm{7,} \mathrm{and} 9$ for morphine; and $\mathrm{pH} \mathrm{5,} \mathrm{6,} \mathrm{7,} \mathrm{8,}$ and 9 for codeine) (Figure S1). No obvious differences were observed between the filtration quenching method and the reductant quenching method (Figure S2) and no measurable adsorption by $\mathrm{MnO}_{2}$ was observed by the four controlled substances.

The $\mathrm{MnO}_{2}$ experiments revealed that ketamine and methamphetamine were persistent and were not oxidized by $10 \mathrm{mg} / \mathrm{L} \mathrm{MnO}_{2}$. However, morphine and codeine were oxidized by $\mathrm{MnO}_{2}$, indicating that they may undergo attenuation in natural soil and sediment environments (Figure 1). Based on the kinetic model reported by Zhang et al. [11], the oxidation of morphine and codeine follows second-order kinetics with adsorption as the rate-limiting step. The second-order kinetics of this process are shown in (1), where $k_{1}, k_{-1}$, and $k_{2}$ present the adsorption rate constant of the compound by $\mathrm{MnO}_{2}$, the desorption rate constant of the compound by $\mathrm{MnO}_{2}$, and the electron transfer rate constant, respectively. Because the adsorption reaction is considerably slower than the electron transfer reaction, the amount of target compound (morphine and codeine) adsorbed on $\mathrm{MnO}_{2}$ but unreacted would be negligible for detection as observed by the experiments. Consider

$$
-\frac{d C}{d t}=\frac{k_{1} k_{2}\left[S_{\mathrm{rxn}}-\left(C_{0}-C\right)\right] C}{k_{-1}+k_{2}}=k^{\prime \prime}\left[S_{\mathrm{rxn}}-\left(C_{0}-C\right)\right] C .
$$

3.1. Effects of $p H$. An initial environmentally relevant concentration was selected for the four controlled drugs $(100 \mu \mathrm{g} / \mathrm{L})$. Ketamine and methamphetamine remained stable against $\mathrm{MnO}_{2}$ oxidation $(4 \mathrm{mg} / \mathrm{L}$ ) at $\mathrm{pH} 4$ and 5 for $48 \mathrm{~h}$ (Figure S3). However, the degradation behaviors of morphine and codeine were different from that of ketamine and methamphetamine. In this study, different $\mathrm{MnO}_{2}$ loadings were used for morphine and codeine $\left(100 \mu \mathrm{g} / \mathrm{L} \mathrm{MnO}_{2}\right.$ for morphine and $8 \mathrm{mg} / \mathrm{L} \mathrm{MnO}_{2}$ for codeine) because morphine is oxidized by $\mathrm{MnO}_{2}$ much more readily than codeine. The results showed that morphine and codeine exhibited lower degradation rates as the solution $\mathrm{pH}$ decreased (Figure 2). Morphine was $>99 \%, 91.5 \%$, and $82 \%$ degraded at $\mathrm{pH} 5,7$, and 9 , respectively (reaction time $=4 \mathrm{~h}, \mathrm{MnO}_{2}=100 \mu \mathrm{g} / \mathrm{L}$ ). Codeine was $>99 \%, 96 \%, 67 \%, 36 \%$, and $28 \%$ degraded at $\mathrm{pH} 5,6,7$, 8 , and 9, respectively (reaction time $=1 \mathrm{~h}, \mathrm{MnO}_{2}=8 \mathrm{mg} / \mathrm{L}$ ). Previous studies indicated that the oxidation of compounds by synthesized $\mathrm{MnO}_{2}$ is a surface reaction and that the surface charge of $\mathrm{MnO}_{2}$ is negative (point of zero charge (PZC) of $\mathrm{MnO}_{2}$ was 2.25) [12,13]. Therefore, the intensity of the negative $\mathrm{MnO}_{2}$ charge increased as the $\mathrm{pH}$ increased from 5 to 9. This increase caused the $\mathrm{MnO}_{2}$ surface to become more hydrophilic and subsequently reduced the number of accessible active sites for the target compound because of obstruction from the nearby water molecules, 


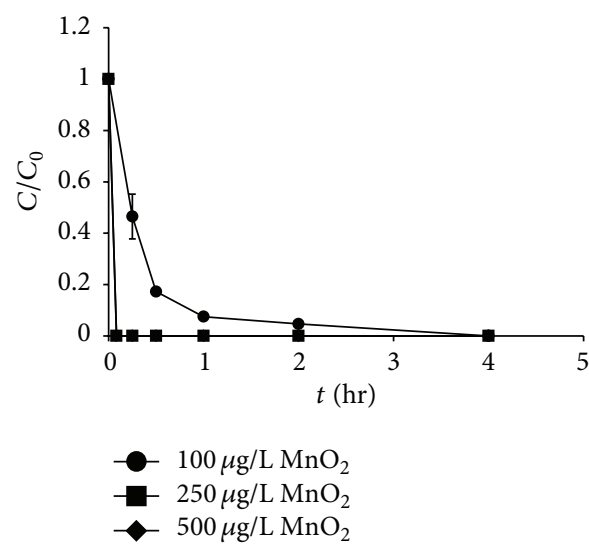

(a)

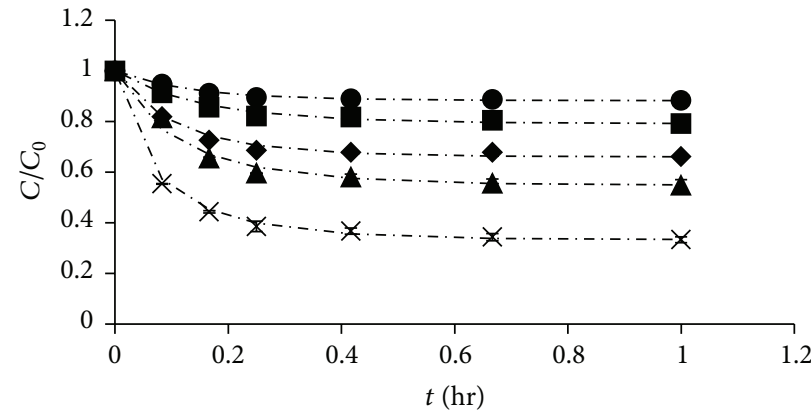

$\begin{array}{ll}\text { - } & 1 \mathrm{mg} / \mathrm{L} \mathrm{MnO}_{2} \\ \text { - } & 2 \mathrm{mg} / \mathrm{LnO}_{2} \\ \text { } & 4 \mathrm{mg} / \mathrm{LnO}_{2} \\ \text { - } & 6 \mathrm{mg} / \mathrm{LnO}_{2} \\ \times \quad & 8 \mathrm{mg} / \mathrm{LnO}_{2}\end{array}$
... $1 \mathrm{mg} / \mathrm{L} \mathrm{MnO}_{2}$ model

... $2 \mathrm{mg} / \mathrm{L} \mathrm{MnO}_{2}$ model

. . . $4 \mathrm{mg} / \mathrm{L} \mathrm{MnO}_{2}$ model

. . - $6 \mathrm{mg} / \mathrm{L} \mathrm{MnO}_{2}$ model

... $8 \mathrm{mg} / \mathrm{L} \mathrm{MnO}_{2}$ model

(b)

Figure 3: Effect of $\mathrm{MnO}_{2}$ loading on the oxidation of controlled substances by $\mathrm{MnO}_{2}$ : (a) morphine and (b) codeine (morphine and codeine $=100 \mu \mathrm{g} / \mathrm{L}, \mathrm{pH}=7$, and ionic strength $=10 \mathrm{mM}$ ) (the second-order kinetic model developed by Zhang et al. [11] was fitted to describe the codeine oxidation).

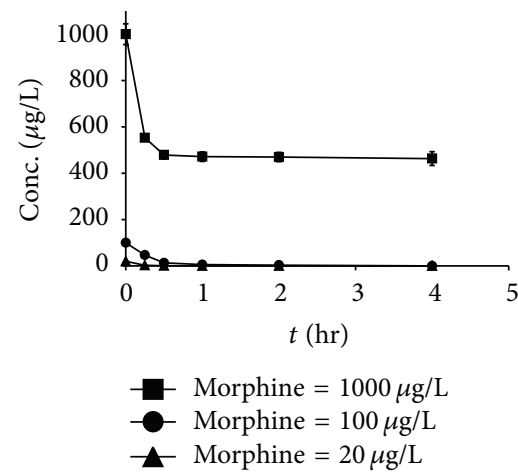

(a)

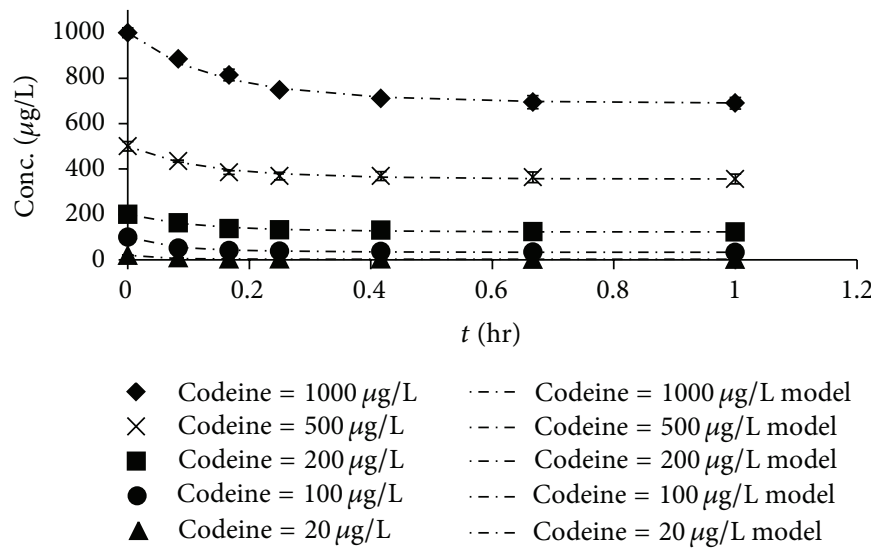

(b)

FIGURE 4: Effect of initial compound concentration on the oxidation of controlled substances by $\mathrm{MnO}_{2}$ : (a) morphine (with $100 \mu \mathrm{g} / \mathrm{L} \mathrm{MnO}$ ) and (b) codeine (with $\left.8 \mathrm{mg} / \mathrm{L} \mathrm{MnO}_{2}\right)(\mathrm{pH}=7$, ionic strength $=10 \mathrm{mM}$ ) (the second-order kinetic model developed by Zhang et al. [11] was fitted to describe the codeine oxidation).

which further reduced the reaction rate [14]. Lin et al. [15] also demonstrated that the ability of $\mathrm{MnO}_{2}$ to oxidize organic compounds is $\mathrm{pH}$-dependent. Furthermore, Stumm and Morgan [16] reported that the $\mathrm{MnO}_{2}$ reduction potential decreased from $0.99 \mathrm{~V}$ to $0.76 \mathrm{~V}$ when the $\mathrm{pH}$ increased from 4 to 8 . Zhang and Huang [17] also reported that more surface species are produced at lower $\mathrm{pH}$ that subsequently react with the reductants. In addition, Klausen et al. [18] indicated that protons are required to dissociate the reaction product $\mathrm{Mn}(\mathrm{II})$ from the $\mathrm{MnO}_{2}(\mathrm{Mn}(\mathrm{IV}))$ mineral surface $\left((1 / 2) \mathrm{Mn}^{\mathrm{IV}} \mathrm{O}_{2(\mathrm{~s})}+2 \mathrm{H}^{+}+\mathrm{e}^{-} \rightleftarrows(1 / 2) \mathrm{Mn}^{2+}+\mathrm{H}_{2} \mathrm{O}\right)$. Therefore, a higher solution $\mathrm{pH}$ may result in a lower degradation rate.

3.2. Effect of $\mathrm{MnO}_{2}$ Loading. The results showed that ketamine and methamphetamine were still present after $\mathrm{MnO}_{2}$ oxidation for $48 \mathrm{hrs}$ unless the $\mathrm{MnO}_{2}$ loading reached $750 \mathrm{mg} / \mathrm{L}$ (Figure S4). High $\mathrm{MnO}_{2}$ loading (750 mg/L) indicates that ketamine and methamphetamine are not degraded by natural $\mathrm{MnO}_{2}$ in soils and sediments. For morphine and codeine, higher $\mathrm{MnO}_{2}$ loadings resulted in a faster oxidation rate (Figure 3 ). The degradation rates of morphine by 250 and $500 \mu \mathrm{g} / \mathrm{L} \mathrm{MnO}_{2}$ were faster than that by $100 \mu \mathrm{g} / \mathrm{L} \mathrm{MnO}_{2}$. Similarly, when $\mathrm{MnO}_{2}$ increased from $1 \mathrm{mg} / \mathrm{L}$ to $8 \mathrm{mg} / \mathrm{L}$, the degradation efficiency of codeine increased from $12 \%$ to $65 \%$ in $1 \mathrm{~h}$. Zhang et al. [11] reported that a precursor complex between the organic compound and $\mathrm{MnO}_{2}$ is formed before electron transfer reaction occurs during the redox reaction. These two steps (precursor complex formation and electron transfer reaction) were hypothesized to be rate-limiting steps and to influence the reactivities of organic compounds and $\mathrm{MnO}_{2}$. Thus, the oxidation of organic compounds by $\mathrm{MnO}_{2}$ 


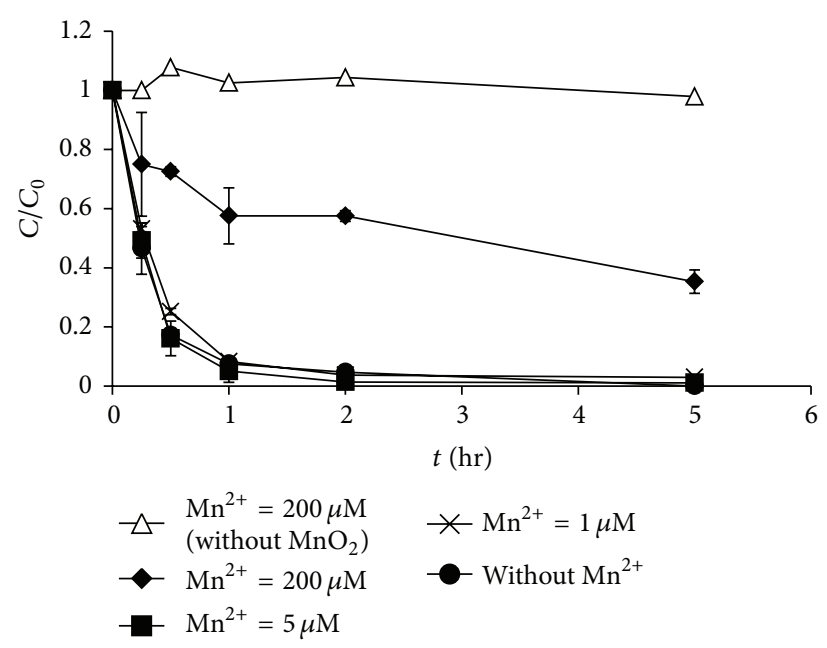

(a)

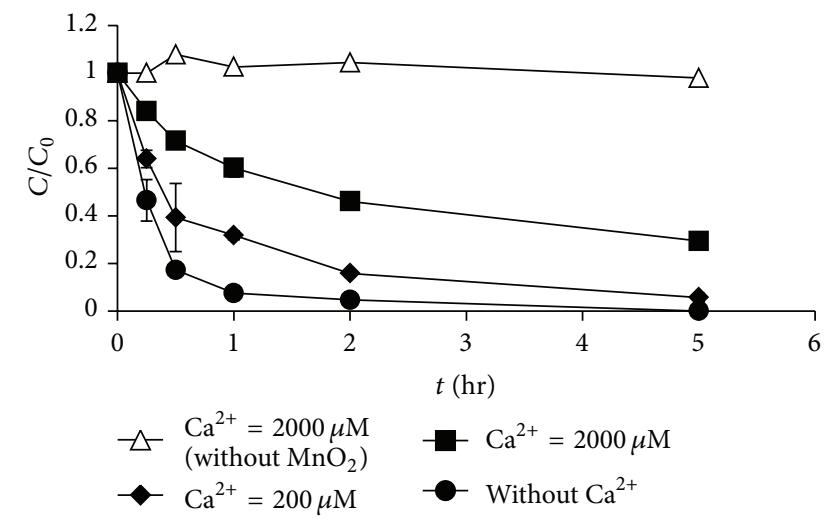

(c)

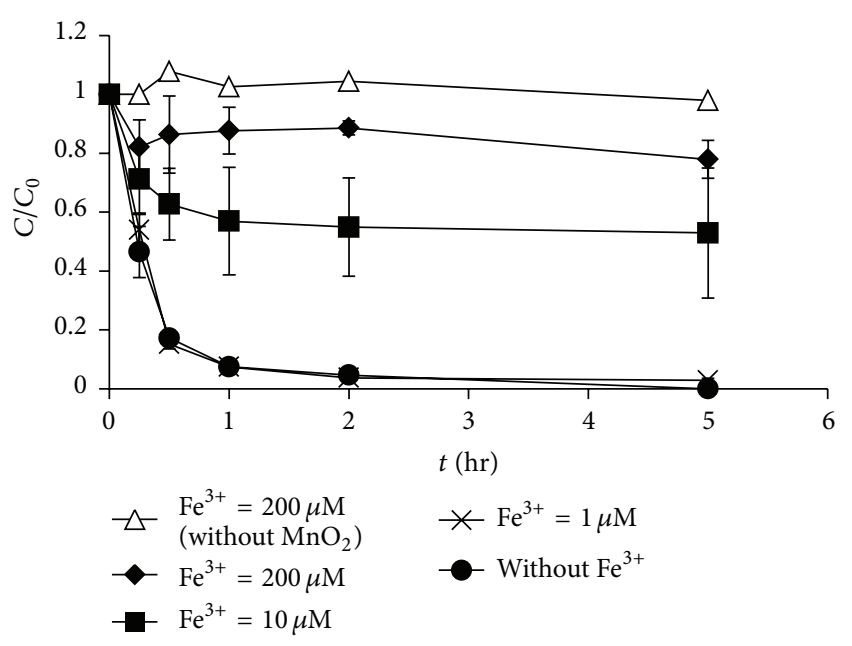

(b)

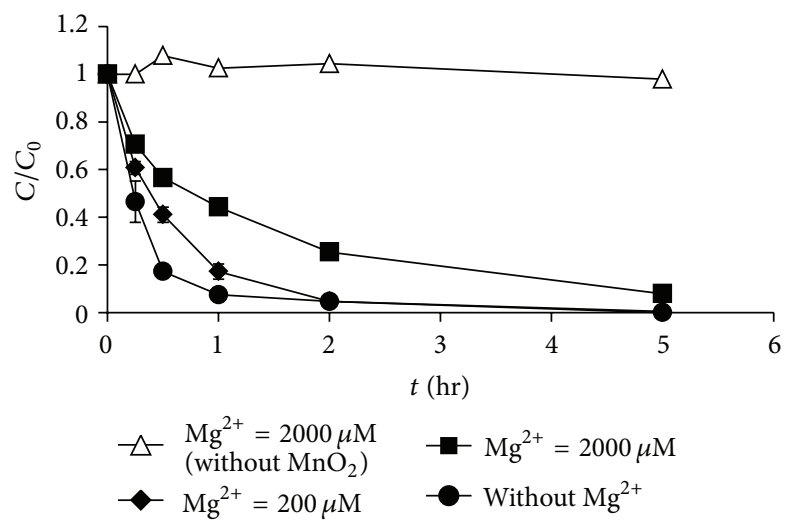

(d)

FIGURE 5: Effect of metal ions on the oxidation of morphine by $\mathrm{MnO}_{2}$ : (a) $\mathrm{Mn}^{2+}$, (b) $\mathrm{Fe}^{3+}$, (c) $\mathrm{Ca}^{2+}$, and (d) $\mathrm{Mg}^{2+}\left(\mathrm{MnO}_{2}\right.$ loading $=100 \mu \mathrm{g} / \mathrm{L}$, initial morphine concentration $=100 \mu \mathrm{g} / \mathrm{L}, \mathrm{pH}=7$, and ionic strength $=10 \mathrm{mM}$ ).

resulted from surface reactions between the $\mathrm{MnO}_{2}$ and compounds [10]. Consequently, when the $\mathrm{MnO}_{2}$ concentration increased, the potential for contact between the target compounds and $\mathrm{MnO}_{2}$ increased and resulted in the reaction. Furthermore, Zhang and Huang [17] reported that higher $\mathrm{MnO}_{2}$ concentrations offer more active surface sites, which resulted in an increase in the rate of precursor complex formation.

3.3. Effects of the Initial Compound Concentration. It has been hypothesized that the formation of a surface complex is the rate-limiting step in the oxidation of morphine and codeine by $\mathrm{MnO}_{2}$. The formation rate of such a surface complex is affected by the $\mathrm{MnO}_{2}$ loading, solution conditions ( $\mathrm{pH}$ and ionic strength), and the initial concentration of the target compound. In this study, the initial compound concentration (morphine and codeine) range was 20 to $1,000 \mu \mathrm{g} / \mathrm{L}$. The results showed that increasing compound concentrations resulted in decreased degradation efficiency (Figure 4) when the $\mathrm{MnO}_{2}$ loading and $\mathrm{pH}$ were fixed. A higher compound concentration could result in self-competition for the fixed number of active sites on the surface of $\mathrm{MnO}_{2}$, thereby decreasing the removal rate of morphine and codeine [11].

3.4. Effects of Metal Ions. The effects of metal cations $\left(\mathrm{Mn}^{2+}\right.$, $\mathrm{Fe}^{3+}, \mathrm{Ca}^{2+}$, and $\mathrm{Mg}^{2+}$ ) on the oxidation of morphine and codeine by $\mathrm{MnO}_{2}$ were investigated (Figures 5 and 6). Previous studies showed that dissolved cations in real water matrices may inhibit the degradation of compounds by $\mathrm{MnO}_{2}$ $[11,17]$. Our results showed a similar phenomenon, in which the coexistence of metal ions resulted in an inhibitory effect on the oxidation of morphine and codeine by $\mathrm{MnO}_{2}$ (except for the effect of $\mathrm{Fe}^{3+}$ on the oxidation of codeine). The degradation of morphine by $\mathrm{MnO}_{2}$ was inhibited more when the concentrations of the metal cations $\left(\mathrm{Mn}^{2+}, \mathrm{Fe}^{3+}, \mathrm{Ca}^{2+}\right.$, and $\mathrm{Mg}^{2+}$ ) increased. For example, as the $\mathrm{Mn}^{2+}$ concentration increased from 1 to $200 \mu \mathrm{M}$, the degradation efficiency of morphine decreased from $99.0 \%$ to $65.7 \%$ in $4 \mathrm{~h}$. However, when the $\mathrm{Ca}^{2+}$ concentration increased from 200 to $2,000 \mu \mathrm{M}$, the degradation efficiency decreased from $94.3 \%$ to $70.6 \%$. Similarly, the degradation efficiency of codeine decreased when the metal cation concentrations $\left(\mathrm{Mn}^{2+}, \mathrm{Ca}^{2+}\right.$, 


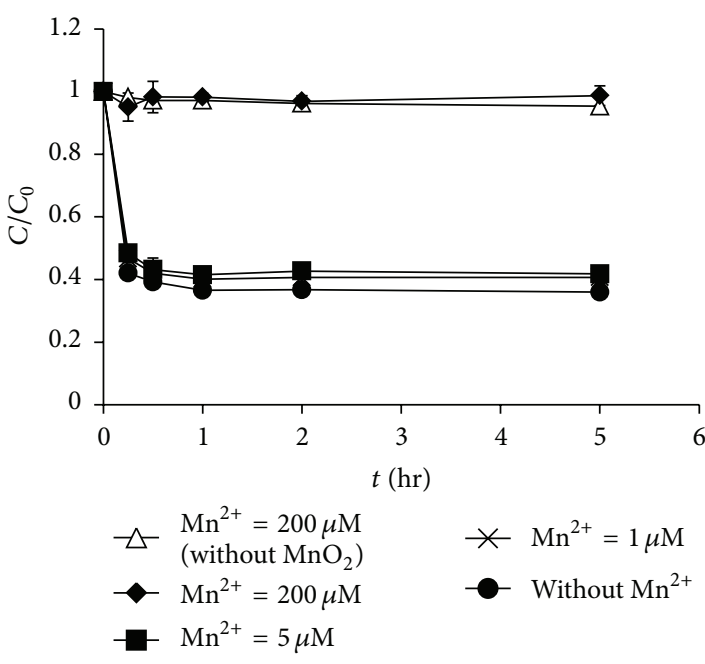

(a)

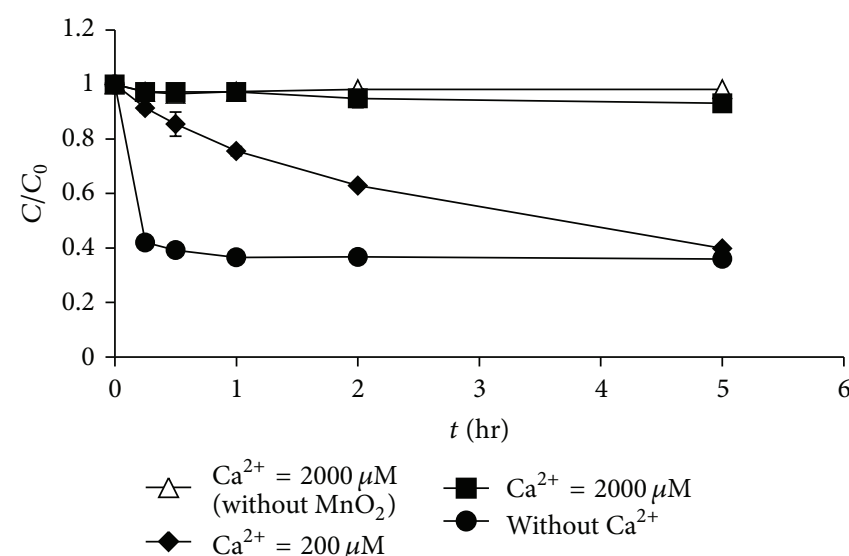

(c)

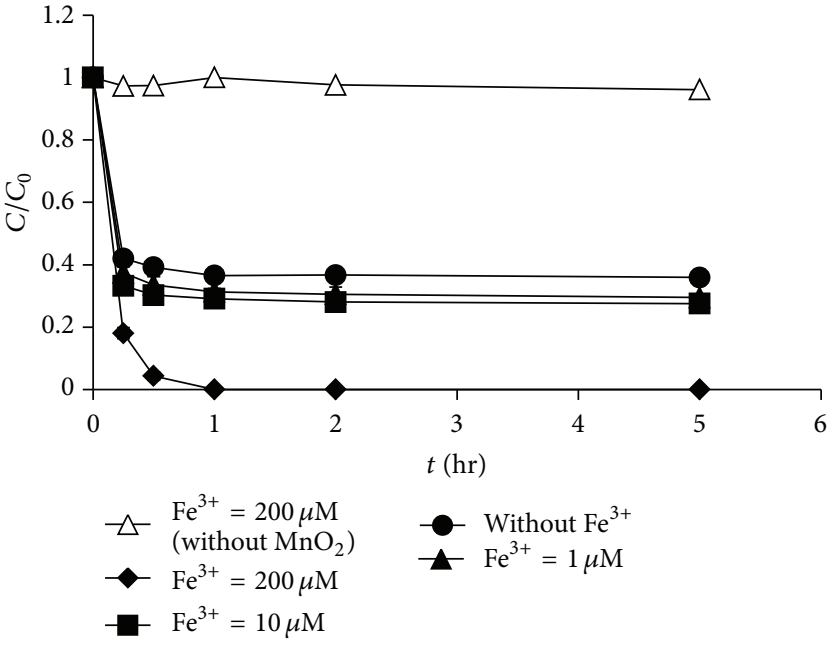

(b)

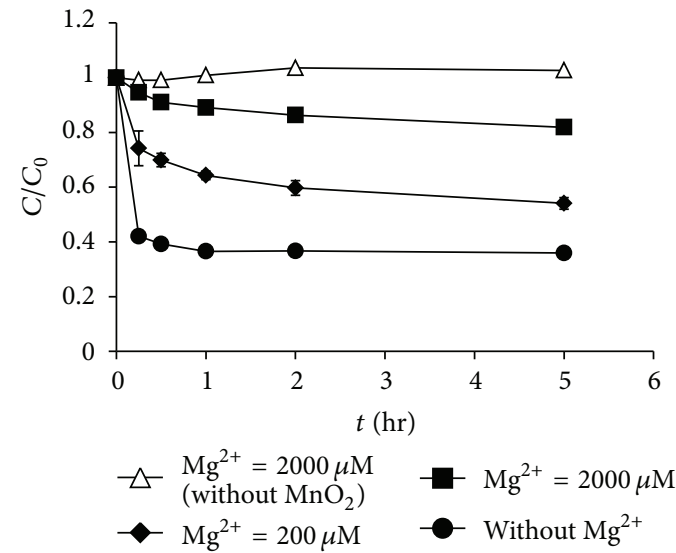

(d)

Figure 6: Effect of metal ions on the oxidation of codeine by $\mathrm{MnO}_{2}$ : (a) $\mathrm{Mn}^{2+}$, (b) $\mathrm{Fe}^{3+}$, (c) $\mathrm{Ca}^{2+}$, and (d) $\mathrm{Mg}^{2+}\left(\mathrm{MnO}_{2}\right.$ loading $=8 \mathrm{mg} / \mathrm{L}$, initial codeine concentration $=100 \mu \mathrm{g} / \mathrm{L}, \mathrm{pH}=7$, and ionic strength $=10 \mathrm{mM}$ ).

and $\mathrm{Mg}^{2+}$ ) increased. However, the opposite phenomenon was observed regarding the effects of $\mathrm{Fe}^{3+}$ on the degradation of codeine $\left(\mathrm{Fe}^{3+}\right.$ enhanced the degradation efficiency of codeine by $\mathrm{MnO}_{2}$ ). As the $\mathrm{Fe}^{3+}$ concentration increased from 1 to $200 \mu \mathrm{M}$, the degradation efficiency of codeine increased from $54.6 \%$ to $100 \%$. One possible explanation for this result is that the addition of $\mathrm{FeCl}_{3}$ at $\mathrm{pH} 7$ could result in coagulation of $\mathrm{MnO}_{2}$ particles, which might reduce the codeine concentration in the solution. The induced coagulation is more likely to occur at the higher $\mathrm{MnO}_{2}$ loading $(8 \mathrm{mg} / \mathrm{L})$ applied for codeine. Further investigations should be performed to understand the detailed mechanisms of $\mathrm{Fe}^{3+}$ toward codeine degradation by $\mathrm{MnO}_{2}$.

\subsection{Effects of Natural Organic Matter. Natural organic matter} (NOM) is present in aqueous environments and is also a factor that may influence the oxidation efficiency of $\mathrm{MnO}_{2}$ [18]. In this work, fulvic acid (FA) was used to represent the NOM in the natural environment. The effects of FA on the oxidation of morphine and codeine by $\mathrm{MnO}_{2}$ are shown in
Figure 7. Results showed that FA decreased the degradation efficiency of morphine, potentially because FA competes with target compounds to the active surface hydroxyl groups of $\mathrm{MnO}_{2}$, resulting in slowing the removal of morphine [21]. In contrast, greater concentrations of FA resulted in slightly greater codeine removal. This result implied that FA did not compete with codeine for the same reactivity sites on $\mathrm{MnO}_{2}$. Another possibility is that the presence of FA might facilitate some aggregation of the $\mathrm{MnO}_{2}$ particles under the experimental conditions used for codeine (with $8 \mathrm{mg} / \mathrm{L} \mathrm{MnO}_{2}$ ). In the absence of $\mathrm{MnO}_{2}, \mathrm{FA}$ alone did not react with morphine or codeine (Figure 7 ), which indicated that the interaction between FA and the target compound (morphine or codeine) did not result in the removal of the target compound.

3.6. Total Organic Carbon (TOC) and Oxidative Byproduct Analysis. The results obtained for the removal of TOC help determine whether the target compounds were mineralized 

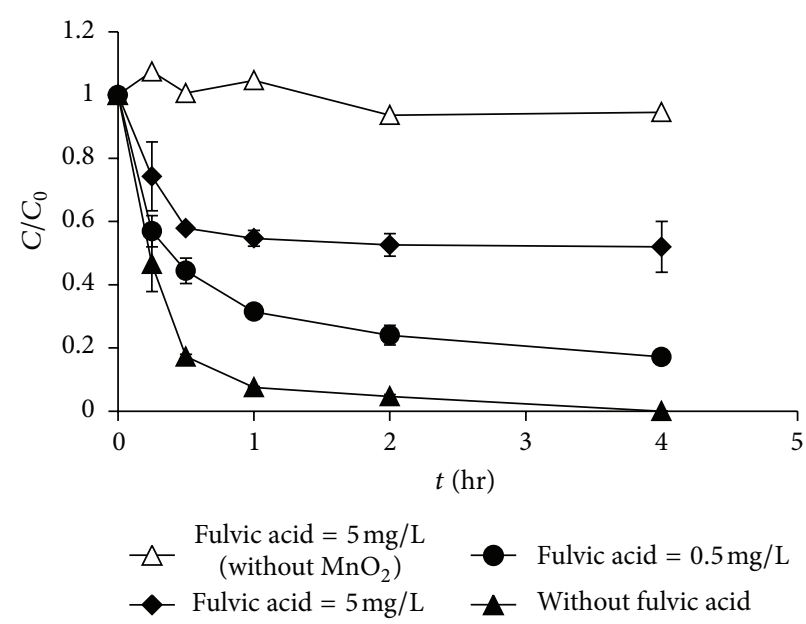

(a)
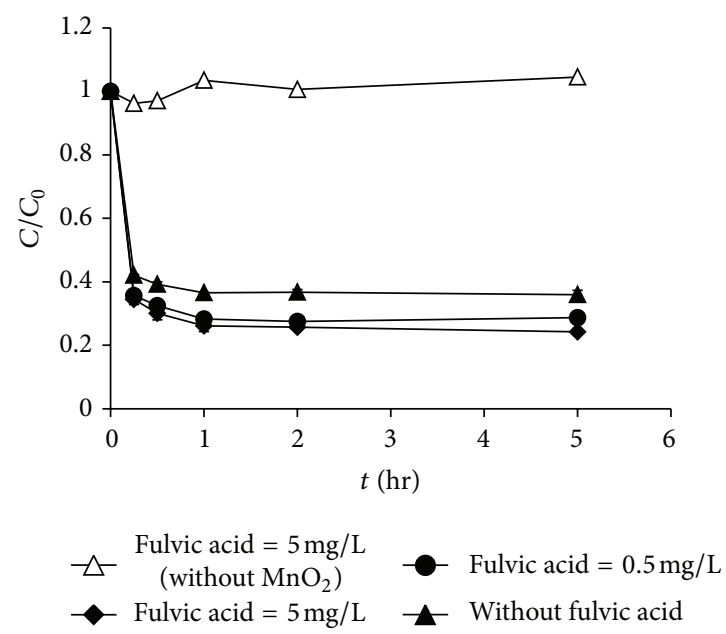

(b)

Figure 7: Effect of fulvic acid on the oxidation of (a) morphine (with $100 \mu \mathrm{g} / \mathrm{L} \mathrm{MnO}_{2}$ ) and (b) codeine (with $8 \mathrm{mg} / \mathrm{L} \mathrm{MnO} 2$ ) (compound concentration $=100 \mu \mathrm{g} / \mathrm{L}, \mathrm{pH}=7$, and ionic strength $=10 \mathrm{mM}$ ).

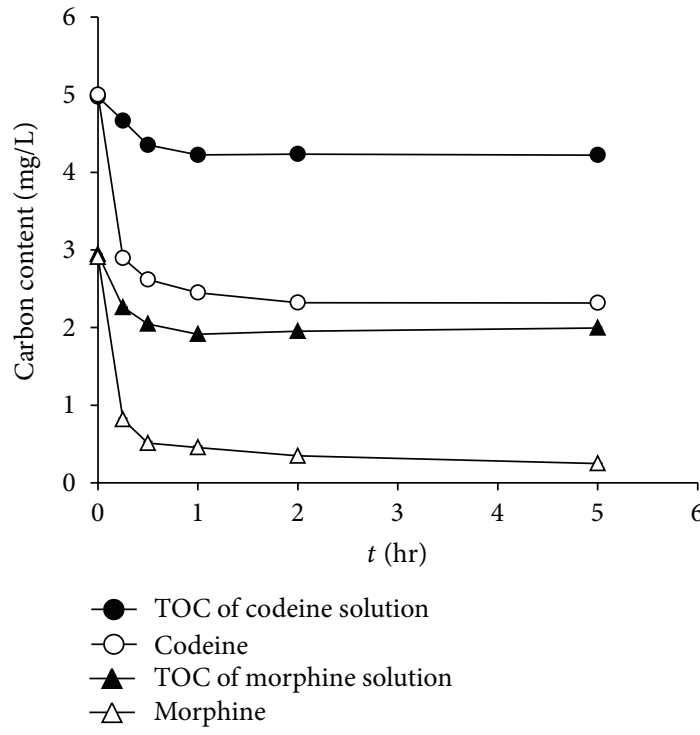

(a)

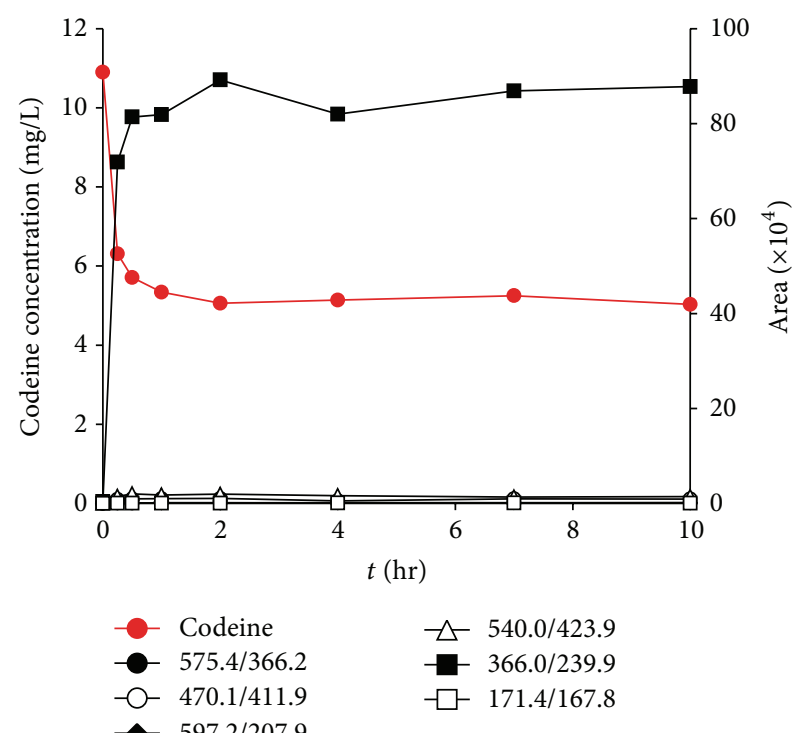

(b)

Figure 8: (a) Target compound degradation and TOC removal of codeine and morphine and (b) byproducts of codeine $\left(\mathrm{MnO}_{2}=8 \mathrm{mg} / \mathrm{L}\right.$, $\mathrm{pH}=7)$.

or transformed into other oxidative transformation byproducts by $\mathrm{MnO}_{2}$. According to Figure 8(a), although $93 \%$ and $54 \%$ of the carbon in morphine and codeine were degraded within $5 \mathrm{~h}$, the TOC removals were only $12 \%$ and $33 \%$, respectively. This result indicated that various degradation byproducts of morphine and codeine were formed. The degradation byproducts of codeine were investigated in a preliminary experiment, as shown in Figure 8(b). The signal corresponding to the byproducts did not decrease during the oxidation of codeine by $\mathrm{MnO}_{2}$, indicating that these byproducts may be persistent and resistant to oxidation by $\mathrm{MnO}_{2}$. In addition, the signal corresponding to the byproducts reached a plateau once the codeine concentration stopped decreasing. This result implied that the formation of byproducts would be affected by the rate of surface complex formation. Among all of the byproducts investigated, the molecular weights of the five byproducts $(\mathrm{m} / z=575.4,470.1,597.2,540.0$, and 366.0) were higher than the parent compound codeine, indicating that these intermediates may be formed by the interaction and combination of the byproducts in the solution. The MS/MS spectra of the oxidative byproducts of codeine are shown in Figure S5. Further work is required to comprehensively investigate the formation of the degradation byproducts and 
their environmental fate and behavior in aqueous environments.

\section{Conclusions}

This study investigated the oxidative transformation of ketamine, methamphetamine, morphine, and codeine by $\mathrm{MnO}_{2}$. Ketamine and methamphetamine were stable against oxidation by $\mathrm{MnO}_{2}$ until $\mathrm{MnO}_{2}$ loading of $750 \mathrm{mg} / \mathrm{L}$ was used, indicating that ketamine and methamphetamine are negligibly degraded by natural $\mathrm{MnO}_{2}$ in soils and sediments and may persist in the environment if no other oxidative pathways are involved. Morphine and codeine were oxidized by $\mathrm{MnO}_{2}$, which indicated that they can be naturally attenuated in aquatic environments with the presence of $\mathrm{MnO}_{2}$. A higher $\mathrm{MnO}_{2}$ loading, a lower $\mathrm{pH}$, and a lower compound concentration resulted in a higher efficiency of morphine and codeine oxidation by $\mathrm{MnO}_{2}$. The kinetic modeling results showed that the oxidation of morphine and codeine followed second-order kinetics and was limited by the rate of the surface precursor complex formation. The presence of metal ions $\left(\mathrm{Mn}^{2+}, \mathrm{Fe}^{3+}, \mathrm{Ca}^{2+}\right.$, and $\left.\mathrm{Mg}^{2+}\right)$ and FA inhibited the oxidation of morphine by $\mathrm{MnO}_{2}$. Although $\mathrm{Mn}^{2+}, \mathrm{Ca}^{2+}$, and $\mathrm{Mg}^{2+}$ suppressed the oxidative efficiency of codeine, $\mathrm{Fe}^{3+}$ and $\mathrm{FA}$ enhanced its degradation, but more research is needed to elucidate the mechanisms. In addition, although the target compounds were degraded, the slow removal of TOC indicated that several byproducts were formed and were even more persistent against further oxidation.

\section{Conflict of Interests}

The authors declare that there is no conflict of interests regarding the publication of this paper.

\section{Acknowledgments}

This work was supported in part by the Ministry of Science and Technology (NSC 101-2621-M-002-018) and in part by the National Health Research Institutes of Taiwan (NHRI-EX10210120PC).

\section{References}

[1] A. Y. C. Lin, T. H. Yu, and S. K. Lateef, "Removal of pharmaceuticals in secondary wastewater treatment processes in Taiwan," Journal of Hazardous Materials, vol. 167, no. 1-3, pp. 1163-1169, 2009.

[2] P. Gao, Y. J. Ding, H. Li, and I. Xagoraraki, "Occurrence of pharmaceuticals in a municipal wastewater treatment plant: mass balance and removal processes," Chemosphere, vol. 88, no. 1, pp. 17-24, 2012.

[3] R. F. Mankes and C. D. Silver, "Quantitative study of controlled substance bedside wasting, disposal and evaluation of potential ecologic effects," Science of the Total Environment, vol. 444, pp. 298-310, 2013.

[4] A. Y.-C. Lin, X.-H. Wang, and C.-F. Lin, "Impact of wastewaters and hospital effluents on the occurrence of controlled substances in surface waters," Chemosphere, vol. 81, no. 5, pp. 562-570, 2010.

[5] A. Y.-C. Lin, W.-N. Lee, and X.-H. Wang, "Ketamine and the metabolite norketamine: persistence and phototransformation toxicity in hospital wastewater and surface water," Water Research, vol. 53, pp. 351-360, 2014.

[6] M. R. Boleda, M. T. Galceran, and F. Ventura, "Monitoring of opiates, cannabinoids and their metabolites in wastewater, surface water and finished water in Catalonia, Spain," Water Research, vol. 43, no. 4, pp. 1126-1136, 2009.

[7] D. Hummel, D. Löffler, G. Fink, and T. A. Ternes, "Simultaneous determination of psychoactive drugs and their metabolites in aqueous matrices by liquid chromatography mass spectrometry," Environmental Science and Technology, vol. 40, no. 23, pp. 7321-7328, 2006.

[8] S. Castiglioni, E. Zuccato, E. Crisci, C. Chiabrando, R. Fanelli, and R. Bagnati, "Identification and measurement of illicit drugs and their metabolites in urban wastewater by liquid chromatography-tandem mass spectrometry," Analytical Chemistry, vol. 78, no. 24, pp. 8421-8429, 2006.

[9] C. J. Gurr and M. Reinhard, "Harnessing natural attenuation of pharmaceuticals and hormones in rivers," Environmental Science \& Technology, vol. 40, no. 9, pp. 2872-2876, 2006.

[10] A. T. Stone, "Reductive dissolution of manganese(III/IV) oxides by substituted phenols," Environmental Science \& Technology, vol. 21, no. 10, pp. 979-988, 1987.

[11] H. Zhang, W.-R. Chen, and C.-H. Huang, "Kinetic modeling of oxidation of antibacterial agents by manganese oxide," Environmental Science and Technology, vol. 42, no. 15, pp. 5548$5554,2008$.

[12] J. W. Murray, "The surface chemistry of hydrous manganese dioxide," Journal of Colloid And Interface Science, vol. 46, no. 3, pp. 357-371, 1974.

[13] R. M. McKenzie, "The surface charge on manganese dioxides," Australian Journal of Soil Research, vol. 19, no. 1, pp. 41-50, 1981.

[14] L. Xu, C. Xu, M. Zhao, Y. Qiu, and G. D. Sheng, "Oxidative removal of aqueous steroid estrogens by manganese oxides," Water Research, vol. 42, no. 20, pp. 5038-5044, 2008.

[15] K. Lin, W. Liu, and J. Gan, "Oxidative removal of bisphenol A by manganese dioxide: efficacy, products, and pathways," Environmental Science and Technology, vol. 43, no. 10, pp. 3860$3864,2009$.

[16] W. Stumm and J. J. Morgan, Aquatic Chemistry, John Wiley \& Sons, New York, NY, USA, 1996.

[17] H. Zhang and C.-H. Huang, "Oxidative transformation of triclosan and chlorophene by manganese oxides," Environmental Science and Technology, vol. 37, no. 11, pp. 2421-2430, 2003.

[18] J. Klausen, S. B. Haderlein, and R. P. Schwarzenbach, "Oxidation of substituted anilines by aqueous $\mathrm{MnO}_{2}$ : effect of Co-solutes on initial end quasi-steady-state kinetics," Environmental Science \& Technology, vol. 31, no. 9, pp. 2642-2649, 1997.

[19] B. K. Logan, "Methamphetamine-effects on human performance and behavior," Forensic Science Review, vol. 14, p. 142, 2002.

[20] M. J. O’Neil, The Merck Index: An Encyclopedia of Chemicals, Drugs, and Biologicals, Merck, Kenilworth, NJ, USA, 2006.

[21] Z. J. Lu, K. D. Lin, and J. Gan, "Oxidation of bisphenol F (BPF) by manganese dioxide," Environmental Pollution, vol. 159, no. 10, pp. 2546-2551, 2011. 

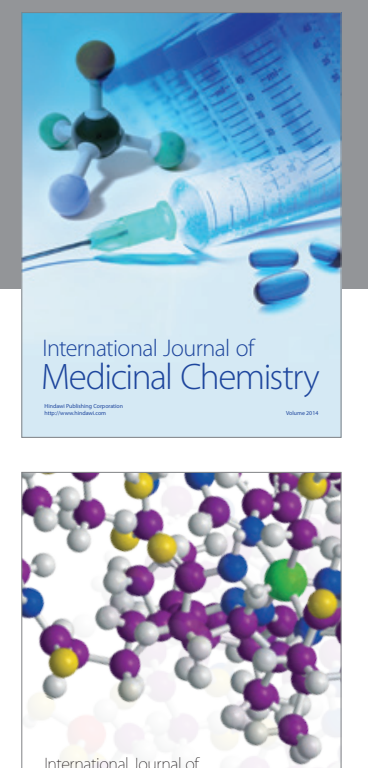

\section{Carbohydrate} Chemistry

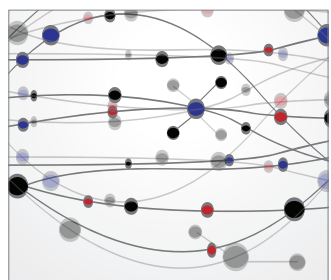

The Scientific World Journal
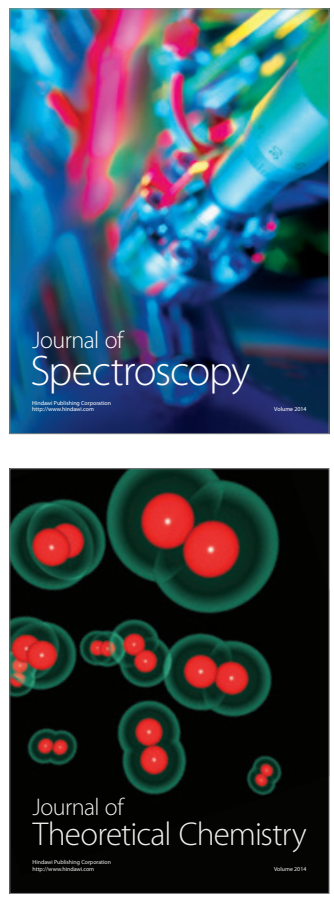
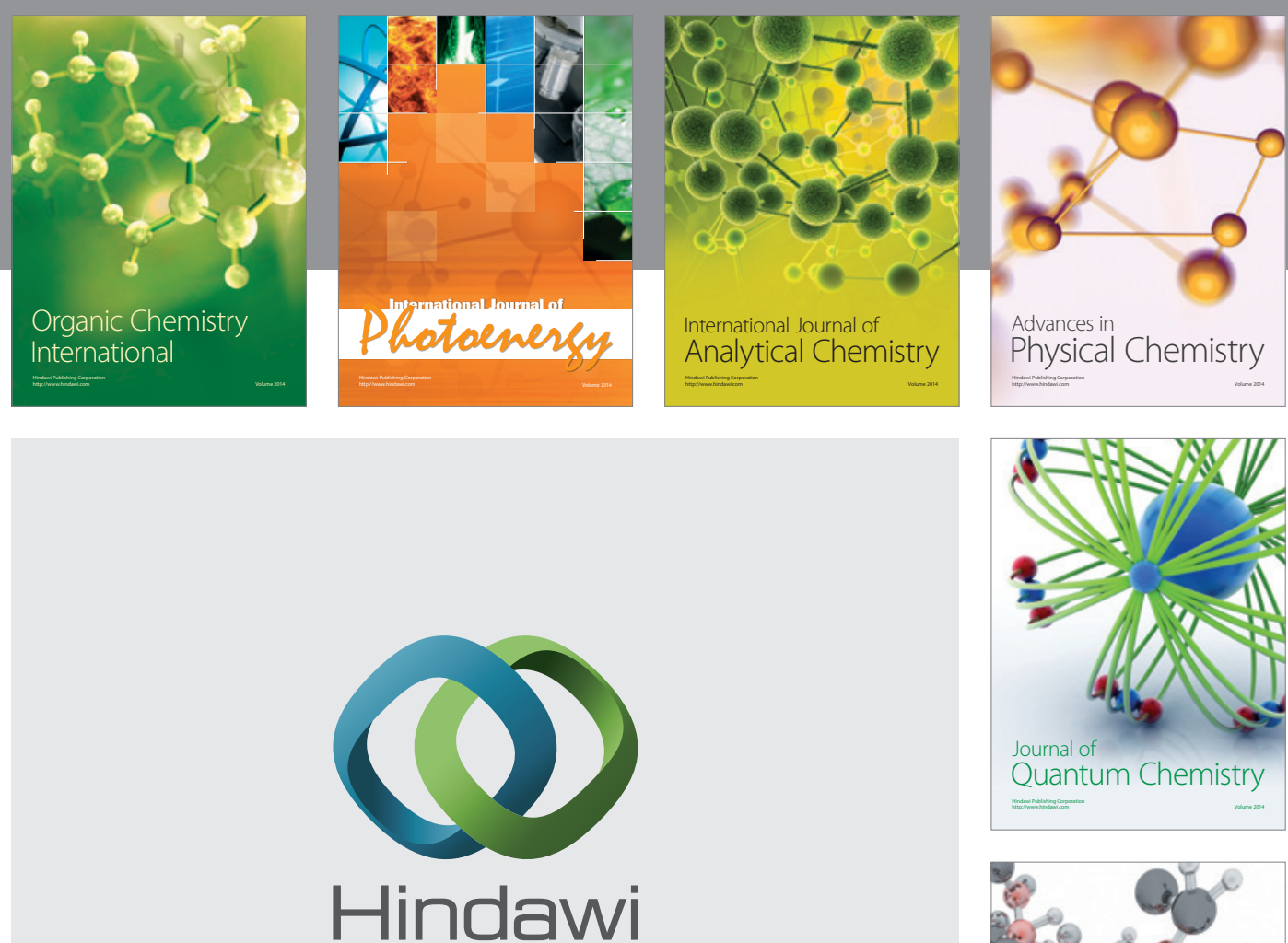

Submit your manuscripts at

http://www.hindawi.com

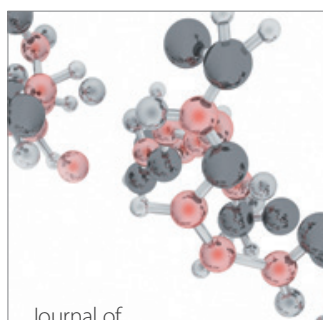

Analytical Methods

in Chemistry

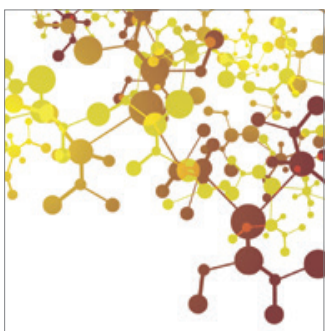

Journal of

Applied Chemistry

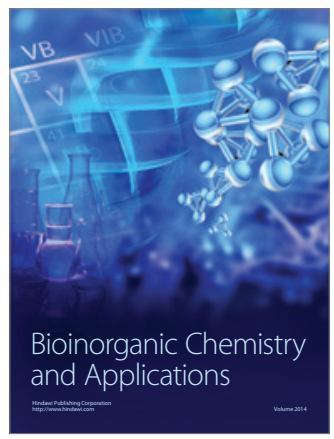

Inorganic Chemistry
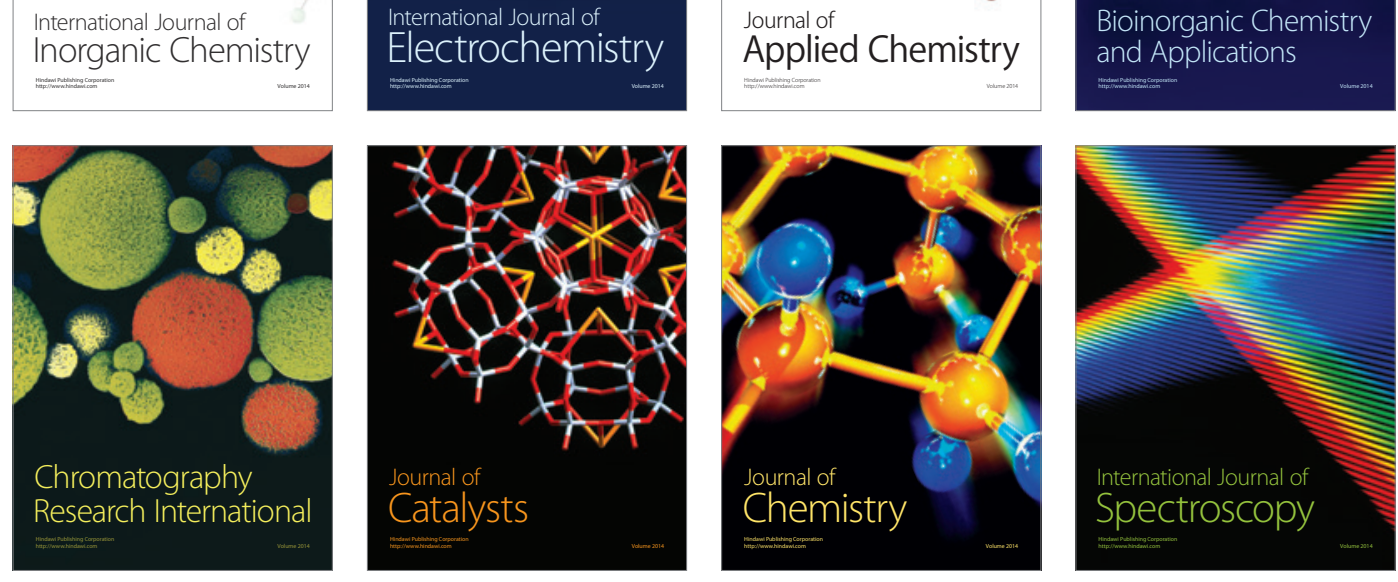